\title{
Erratum to: Casting shadows? Authoritarianism in Putin's Russia
}

\section{Dorothy Horsfield}

Published online: 20 November 2014

(C) Springer-Verlag Berlin Heidelberg 2014

\section{Erratum to: Asia Eur J \\ DOI 10.1007/s10308-014-0393-7}

The original version of this article unfortunately contained mistake. The article title should have been "Casting shadows? Authoritarianism in Putin's Russia" and is now corrected in this article.

The online version of the original article can be found at http://dx.doi.org/10.1007/s10308-014-0393-7.

D. Horsfield $(\bowtie)$

ANU Centre for European Studies (ANUCES), The Australian National University, Canberra, Australia e-mail: Dorothy.Horsfield@anu.edu.au 